\title{
Health biopsychosocial aspects of students and collaborators of a higher education institution suffering from headache
}

\author{
Aspectos biopsicossociais da saúde de estudantes e funcionários de uma instituição de ensino \\ superior portadores de cefaleia
}

Bruna Pereira Pessigatti ${ }^{1}$, Ana Paula Costa Rodrigues ${ }^{1}$, Pâmela Valério Aguiar ${ }^{1}$, Fabiano Moura Dias ${ }^{1}$

DOI 10.5935/2595-0118.20200005

\section{ABSTRACT}

BACKGROUND AND OBJECTIVES: Headache is considered a common health condition in doctors' offices around the world. It is an unpleasant sensory experience that will be experienced by the individual at least once in their life, be it an adult or child. The main challenge is to make an accurate diagnosis due to the signs and symptoms that may be related to other diseases. Its etiology is multifactorial and is often related to the individual's biopsychosocial condition. Thus, headache results in significant physical and emotional impact on the patient. The objective of this study was to identify the biopsychosocial aspects of the health of students and employees with headache from a higher education institution in the city of Vila Velha/ES.

METHODS: This research was a cross-sectional analytical study conducted from March to May 2019. The convenience sample consisted of 51 individuals of both genders, aged between 18 and 59 years old, who reported headaches.

RESULTS: Fifty-one individuals (female $=41$ and male $=10$ ) participated in the study; most individuals were single $(\mathrm{n}=38$, $74.5 \%)$ and had no children ( $\mathrm{n}=40,78.4 \%)$; $62.7 \%$ were students and $32.7 \%$ were employees. The average time since the perception of the symptom was $105 \pm 118.3$ months. According to the visual analog scale, the total average pain was $6.6 \pm 1.8$. The impact of headache was measured by the migraine deficiency assessment questionnaire which showed $52.9 \%$ of individuals with a severe impact. This result resembles sleep disorders $(58.8 \%)$, confirming that the headache is debilitating in the population studied.

Bruna Pereira Pessigatti - (Dhttps://orcid.org/0000-0001-6249-5254;

Ana Paula Costa Rodrigues - Dhttps://orcid.org/0000-0003-2455-7439;

Pâmela Valério Aguiar - (Dhttps://orcid.org/0000-0002-8741-7751;

Fabiano Moura Dias - Dhttps://orcid.org/0000-0002-9163-0037.

1. Universidade Vila Velha, Departamento de Fisioterapia, Vila Velha, ES, Brasil.

Submitted on July 03, 2019.

Accepted for publication on December 10, 2019.

Conflict of interests: none - Sponsoring sources: none.

Correspondence to:

Departamento de Fisioterapia

Av. Comissário José Dantas de Melo, n 21 - Boa Vista

29102-920 Vila Velha, ES, Brasil.

E-mail: crcanapaula@gmail.com

(C) Sociedade Brasileira para o Estudo da Dor
CONCLUSION: It was observed that female students had a higher prevalence of headache and that the most prevalent type of pain is migraine, with an impact on the overall functionality of individuals.

Keywords: Headache, Migraine disorders, Physical therapy specialty, Sleep.

\section{RESUMO}

JUSTIFICATIVA E OBJETIVOS: A dor de cabeça é considerada uma condição de saúde comum em consultórios médicos em todo o mundo. É uma experiencia sensorial desagradável que será experimentada pelo indivíduo, pelo menos uma vez na vida, seja ele adulto ou criança. O principal desafio é realizar um diagnóstico preciso devido aos sinais e sintomas que podem estar relacionados a outras doenças. Sua etiologia é multifatorial e frequentemente está relacionada à condição biopsicossocial do indivíduo. Dessa forma, a cefaleia resulta em grande impacto físico e emocional no paciente. O objetivo deste estudo foi conhecer os aspectos biopsicossociais da saúde de estudantes e funcionários com dor de cabeça em uma instituição de ensino superior da cidade de Vila Velha/ES.

MÉTODOS: Trata-se de um estudo do tipo transversal analítico, realizado entre março e maio de 2019. A amostra foi de conveniência e composta por 51 indivíduos, de ambos os sexos, com idade entre 18 e 59 anos e que apresentassem relato de dor de cabeça.

RESULTADOS: Cinquenta e um indivíduos (feminino $=41$ e masculino=10) participaram do estudo; a maioria dos indivíduos era solteira $(n=38,74,5 \%)$ e não tinha filhos $(n=40,78,4 \%) ; 62,7 \%$ eram estudantes e $32,7 \%$ eram empregados. O tempo médio de percepção dos sintomas foi de $105 \pm 118,3$ meses. De acordo com a escala analógica visual, a dor média total foi de $6,6 \pm 1,8$. O impacto da dor de cabeça foi mensurado pelo questionário de avaliação da deficiência de enxaqueca que apresentou 52,9\% dos indivíduos com um impacto grave. Esse resultado se assemelha aos distúrbios do sono $(58,8 \%)$, confirmando que a dor de cabeça é debilitante na população estudada.

CONCLUSÁO: Observou-se que as mulheres estudantes apresentaram maior prevalência de cefaleia e que o tipo de dor mais prevalente é a enxaqueca, com impacto na funcionalidade geral dos indivíduos.

Descritores: Cefaleia, Fisioterapia, Sono, Transtornos de enxaqueca. 


\section{INTRODUCTION}

The evaluation by the biopsychosocial model considers that the human body is a complex organism, influenced by several factors. Under this conception, health and disease are dynamically balanced conditions and are determined by biological, psychological, and social variables, all in constant interaction. Diagnosis, prevention and treatment of diseases should consider the contributions of these three sets of variables. Thus, the best way to take care of people is to consider that the etiology of health conditions is always multifactorial ${ }^{1}$.

Headache is commonly known as a disabling health condition since ancient times ${ }^{2,3}$. However, only in 1988, the International Headache Society (HIS) suggested, through the publication of the article "Classification and Diagnostic Criteria of Headache", guidelines for classifying and diagnosing headaches according to their etiology $y^{4}$.

Headaches are referred to as primary when there is no attribution of a specific cause, for example, migraine type, tension-type headache (TTH), or trigeminal autonomic. They are considered secondary when associated with another disorder or the consequence of aggression to the organism, of general or neurological nature, such as trauma, tumors, excess drugs, among others ${ }^{4,5}$.

Among the headache types, TTH and episodic migraine are the most prevalent in the world population. Despite affecting both genders, TTH predominance is higher in females, at working age, between 30 and 39 years-old ${ }^{6}$.

The social impact of headache is associated with school and work absenteeism, as well as reduced productivity, both school and economic, in the affected population ${ }^{7,8}$. The personal implications of headache are directly related to changes in personality, lifestyle, constant physical and psychological stress. Also, personal factors such as education, financial condition, and marital status are described as capable of influencing the clinical presentation of this health condition ${ }^{9-11}$.

The presence of headaches in college students is increasingly common, overcoming the headache presence in workers. In this population, it is assumed that there is an association between the presence of headache with factors such as student overload, stress, irritability, insomnia, and depression. In addition, headache can influence family relationships and cause dissatisfaction with the studies of the affected individuals ${ }^{12,13}$. According to the biopsychosocial model, as important as identifying the disease is knowing whether the individual can work, perform their daily activities at work, at school, or in other social areas. Thus, defining and measuring disabilities enables to design and monitor the impact of health or health-related interventions. To this end, the World Health Organization (WHO) has developed the WHO Disability Assessment Schedule (Whodas 2.0), which provides a standardized cross-cultural health and disability measurement model $^{14}$. Whodas 2.0 provides a universal measurement system for the impact of any health condition on functionality but has not yet been used to assess headache in patients.
Thus, this study aimed at knowing the biopsychosocial health aspects of students and employees with headache from a university in the city of Vila Velha/ES.

\section{METHODS}

This is a cross-sectional analytical study. Students and employees of a higher education institution in the municipality of Vila Velha were invited to participate in the research. The project was publicized by the university's social media and banners posted around the campus. The inclusion criteria were any gender, aged between 18 and 59 years, studying or working at the university and with a headache report. The exclusion criteria were fibromyalgia, temporomandibular disorders, neurological disorders, cardiovascular disorders, neoplasia, pregnant women, or not meeting the defined ICDH$-3 \beta$ diagnostic criteria. Fifty-three individuals enrolled in the project, but only the 51 who met the inclusion criteria were included.

A questionnaire was used to evaluate sociodemographic variables, including issues classifying headache according to the criteria established by the Headache International Classification of the Brazilian Headache Society ${ }^{4}$. The visual analog scale (VAS) was used to classify the headache intensity at the evaluation moment, and the average headache pain in the last three months ${ }^{15}$.

The Migraine Disability Assessment (MIDAS) questionnaire was applied to rate the disability caused by headache in relation to professional and social life. It has seven questions related to work, social, family, and leisure activities in the last three months, besides analyzing the intensity and frequency of headache episodes ${ }^{16,17}$. The impact of headache frequency on quality of life was assessed by the Headache Impact Test (HIT-6). This instrument has six items related to pain, social, psychological cognitive functioning and distress ${ }^{18,19}$.

The McGill questionnaire, designed to provide qualitative pain measures that can be statistically analyzed ${ }^{20}$, was used to characterize the sensory-discriminative, affective-motivational, cognitive, evaluative, and miscellaneous aspects of individuals with headache belonging to this research ${ }^{21}$.

The health and disability assessment was performed using the WHO Disability Assessment Schedule generic questionnaire version 2.0, 12 items (Whodas), which has six domains: cognition, mobility, self-care, interpersonal relationships, life activities, and participation in the last 30 days $^{14}$. Sleep quality was also assessed by the Pittsburgh Sleep Quality Index (PSQI) through 19 questions that addressed subjective sleep quality, the occurrence of disorders, latency, duration, sleep aid, and daily sleep dysfunction to keep awake while performing some activity 22 .

The Institution's Ethics Committee approved this study under opinion No. 3,162,150 of 2019.

\section{Statistical analysis}

The results were shown in absolute and relative frequency, mean and standard deviation of the mean. After the Shapiro 
Wilk's normality test, it was observed that the variables did not have a Gaussian distribution and, therefore, for the correlation analysis, the Spearman correlation coefficient was used. To identify the correlation strength between the variables analyzed, it was assumed that the values of 0.0-0.29 indicated a weak correlation, $0.30-0.59$ a moderate one, 0.60 to 0.89 a strong one and 0.90 to 1.00 a very strong one. All statisti$\mathrm{cal}$ analyses were performed using the Prism Pad Graph 5.0 software (GraphPad Software Inc., California), and a value of $\mathrm{p} \leq 0.05$ was considered statistically significant.

\section{RESULTS}

Fifty-one female participants $(\mathrm{n}=41,80.4 \%)$ with a mean age of 28 years-old $($ minimum $=18$ and maximum $=59$ ) were evaluated. Most were single $(\mathrm{n}=38,74.5 \%)$ and had no children $(n=40,78.4 \%)$, and the number of students outnumbered employees $(n=32,62.7 \% ; n=19,37.3 \%$, respectively) (Table 1).

The specific characteristics related to pain and its interference in the daily lives of individuals are summarized in table 2 . The average time of symptom perception was $105 \pm 118.3$ months ( minimum $=5$ months and maximum $=432$ months).

At the time of the interview, 29 subjects reported headaches, with a mean pain intensity of $4 \pm 1.8$ by VAS. In the pain assessment of the last three months, the VAS mean was 6.6 $6 \pm 1.8$. Most individuals reported bilateral pain $(\mathrm{n}=28,54.9 \%)$, stable in relation to the onset of pain perception $(n=22,43.1 \%)$, with several recurrences in the month $(\mathrm{n}=16,31,4 \%)$, worsening in the afternoon $(\mathrm{n}=19,37.3 \%)$, and was mainly accompanied by photophobia symptom $(\mathrm{n}=37,72.5 \%)$, stress in the workplace $(n=33,63 \%)$ and at home $(n=26,51 \%)$. Most reported perfectionism ( $\mathrm{n}=28,54.9 \%)$.

Qualitatively, the pain was assessed using the McGill questionnaire through the sensory, affective, cognitive, and mis-

Table 1. Characteristics of research participants $(n=51)$

\begin{tabular}{lcc}
\hline Variables & Absolute frequency & Relative frequency (\%) \\
\hline Gender & 41 & 80.4 \\
Female & 10 & 19.6 \\
Male & & \\
Marital status & 38 & 74.5 \\
Single & 12 & 23.5 \\
Married & 1 & 2.0 \\
Divorced & & \\
Occupation & 19 & 37.3 \\
Employee & 32 & 62.7 \\
Student & & \\
Number of children & 40 & 78.4 \\
0 & 7 & 13.7 \\
1 & 3 & 5.9 \\
2 & 1 & 2.0 \\
4 & & \\
\hline
\end{tabular}

Table 2. Pain characteristics and effect on daily life $(n=51)$

\begin{tabular}{|c|c|c|}
\hline \multicolumn{3}{|l|}{ Variables } \\
\hline $\begin{array}{l}\text { Symptom perception (months) } \\
\text { (Mean } \pm \text { SD) }\end{array}$ & \multicolumn{2}{|c|}{$105.0 \pm 118.3$} \\
\hline Current pain (Mean \pm SD) & \multicolumn{2}{|c|}{$2.3 \pm 2.4$} \\
\hline Pain in the last 3 months (Mean \pm SD) & \multicolumn{2}{|c|}{$6.6 \pm 1.8$} \\
\hline Pain location & $\begin{array}{l}\text { Absolute } \\
\text { frequency }\end{array}$ & $\begin{array}{c}\text { Relative } \\
\text { frequency (\%) }\end{array}$ \\
\hline Unilateral & 23 & 45.1 \\
\hline Bilateral & 28 & 54.9 \\
\hline \multicolumn{3}{|l|}{ Condition relationship } \\
\hline Improves & 12 & 23.5 \\
\hline Stable & 22 & 43.1 \\
\hline Worsens & 17 & 33.3 \\
\hline \multicolumn{3}{|l|}{ Symptom frequency } \\
\hline Less than once a month & 7 & 13.7 \\
\hline Once a month & 6 & 11.8 \\
\hline Many times per month & 16 & 31.4 \\
\hline Many times per week & 15 & 29.4 \\
\hline Continuously & 7 & 13.7 \\
\hline \multicolumn{3}{|l|}{ Worst moment } \\
\hline When getting up & 8 & 15.7 \\
\hline In the morning & 6 & 11.8 \\
\hline In the afternoon & 19 & 37.3 \\
\hline In the evening & 16 & 31.4 \\
\hline When sleeping & 1 & 2.0 \\
\hline All-day long & 1 & 2.0 \\
\hline \multicolumn{3}{|l|}{ Present symptoms } \\
\hline Photophobia & 37 & 72.5 \\
\hline Nausea & 25 & 49.0 \\
\hline Vomiting & 3 & 5.9 \\
\hline \multicolumn{3}{|l|}{ Influence of pain in the daytime } \\
\hline Stress at work & 32 & 63 \\
\hline Stress at home & 26 & 51.0 \\
\hline Perfectionist behavior & 28 & 54.9 \\
\hline Reduced appetite & 14 & 27.5 \\
\hline Little interest in normal daily activities & 13 & 25.5 \\
\hline Psychiatric/psychological problems & 22 & 43.1 \\
\hline \multicolumn{3}{|l|}{ Headache classification } \\
\hline Tension-type headache & 23 & 45.1 \\
\hline Migraine & 28 & 54.9 \\
\hline
\end{tabular}

cellaneous domains. The total pain index was $42.1 \pm 23.3$, which means a moderate pain index. Their results are described in table 3 . The overall functionality evaluated by Whodas is also presented in table 3 .

Table 4 shows the results related to the disability, impact, and sleep quality degree of people with headache. Pain disability degree evaluation through MIDAS showed that most individuals $(\mathrm{n}=17,33.3 \%)$ had no or minimal disability. This result was followed by 14 individuals $(27.5 \%)$ with a severe disabi- 
Table 3. Qualitative aspects of pain and overall functionality assessment $(n=51)$

\begin{tabular}{lcc}
\hline McGill & Mean \pm SD & Results \\
\hline Sensory-discriminative & $16 \pm 7.1$ & Moderate \\
Affective-motivational & $7.6 \pm 4.4$ & Moderate \\
Cognitive-evaluative & $2.5 \pm 1.2$ & Moderate \\
Miscellaneous & $4.1 \pm 2.8$ & Mild \\
Pain index (Total) & $42.1 \pm 23.3$ & Moderate \\
Whodas & & \\
Daily activities & $3.80 \pm 1.56$ & Moderate \\
Cognitive & $3.57 \pm 1.6$ & Moderate \\
Mobility & $3.61 \pm 1.56$ & Moderate \\
Self-care & $2.37 \pm 0.96$ & Mild \\
Interpersonal relationships & $3.07 \pm 1.56$ & Moderate \\
Participation & $4.0 \pm 1.81$ & Severe \\
Total & $20.43 \pm 6.48$ & \\
\hline
\end{tabular}

Table 4. Disability, impact and sleep quality degree $(n=51)$

\begin{tabular}{lcc}
\hline Instruments & $\begin{array}{c}\text { Absolute } \\
\text { frequency }\end{array}$ & $\begin{array}{c}\text { Relative } \\
\text { frequency (\%) }\end{array}$ \\
\hline Disability & 17 & 33.3 \\
Minimum or none & 10 & 19.6 \\
Mild & 10 & 19.6 \\
Moderate & 14 & 27.5 \\
Severe & & \\
HIT-6 & 6 & 11.8 \\
Little impact & 10 & 19.6 \\
Some impact & 8 & 15.7 \\
Substantial impact & 27 & 52.9 \\
Severe impact & & \\
Sleep quality & 1 & 1.9 \\
Good & 20 & 39.2 \\
Bad & 30 & 58.8 \\
Disorder & &
\end{tabular}

HIT-6 = Headache Impact Test. lity. The impact assessed by HIT-6 shows a predominance of individuals with severe impact $(n=27,52.9 \%)$. Regarding the sleep quality evaluated by PSQI, 30 individuals (58.8\%) had sleep disorders.

Table 5 shows the correlations between the functionality domains addressed by the Whodas instrument and the other variables. Age showed a low correlation (r: 0.290) with the interpersonal relationship domain and no correlation with the other domains. Females showed a moderate correlation only with the social participation domain (r: 0.414) and the frequency of the symptoms denotes moderate correlation with the interpersonal participation domain ( $\mathrm{r}$ : 0.397). By correlating photophobia symptoms, a moderate correlation was found in daily activities ( $\mathrm{r}: 0.352)$ and mobility ( $\mathrm{r}: 0.386)$. The correlation between Whodas and the instruments that assess headache disability, headache impact on the quality of life, sleep quality and pain quality was also analyzed, and MIDAS and HIT-6 did not correlate with self-care domain, while Pittsburg and McGill did not correlate with any of the Whodas domains.

\section{DISCUSSION}

In this study, most individuals with headache had migraines and women are the most affected; in the student group, there was a similarity between the number of individuals with migraine and TTH.

The predominance of individuals with migraine in this study, especially in females, corroborates the findings of a study that evaluated the characteristics of 2000 patients with primary and secondary headache, with a higher incidence of migrai$\mathrm{ne}^{23}$. Other studies found, besides the prevalence of headache in women, a mean age between 25 and 55 years, similar to the results presented in this study ${ }^{6,12}$. In addition, it was observed in this research that the older the person, the lower the impairment of interpersonal relationships, which can be justified by maturity and life-long experience. The evaluated women presented greater impairment of social participation. It is suggested that the fact that women have more frequent

Table 5. Correlation between demographic, disability, headache impact, sleep quality, and pain variables with global functionality domains assessed by Whodas $2.0(n=51)$

\begin{tabular}{|c|c|c|c|c|c|c|}
\hline & Activity & Cognitive & Mobility & Self-care & Relationship & Participation \\
\hline Age & 0.220 & 0.072 & 0.163 & 0.201 & $0.290^{*}$ & 0.0056 \\
\hline Gender & 0.179 & 0.045 & 0.154 & 0.050 & 0.147 & $0.414^{*}$ \\
\hline Symptom frequency & 0.254 & 0.117 & 0.179 & 0.250 & 0.204 & $0.397^{*}$ \\
\hline Psychological & 0.195 & 0.265 & 0.176 & $0.306^{*}$ & 0.251 & 0.248 \\
\hline Photophobia & $0.352^{*}$ & 0.178 & $0.386^{\star}$ & 0.153 & -0.050 & 0.237 \\
\hline Phonophobia & $0.336^{*}$ & 0.111 & 0.202 & 0.146 & 0.054 & 0.285 \\
\hline MIDAS & $0.536^{*}$ & $0.392^{*}$ & $0.552^{*}$ & 0.210 & $0.289^{\star}$ & $0.571^{*}$ \\
\hline HIT-6 & $0.497^{\star}$ & $0.295^{\star}$ & $0.490^{*}$ & 0.195 & $0.383^{*}$ & $0.649^{\star}$ \\
\hline PSQI & -0.271 & 0.135 & 0.088 & 0.084 & 0.007 & 0.030 \\
\hline McGill & 0.198 & 0.139 & 0.187 & 0.150 & 0.098 & 0.230 \\
\hline
\end{tabular}

HIT-6 = Headache Impact Test; PSQI = Pittsburgh Sleep Quality Index; MIDAS = Migraine Disability Assessment. Values shown in r (Spearman correlation); ${ }^{*} \mathrm{p}<0.05$ 
episodes of headache may have hormonal influence, especially in the menstrual period and stress ${ }^{6,24,25}$.

Regarding students, there was an analogy between individuals with migraine and TTH, corroborating a study that included 119 students from a public university in São Paulo, indicating the onset or worsening of headache after university admission, resulting in a decrease in productivity of their student activities $^{26}$.

Regarding marital status, a study showed that married people are susceptible to more episodes of headache, which may be justified by occupational and family demands, added to daily stress $^{27}$. However, this study found that single individuals, mostly students, had a higher rate of headache. This is related to local and individual biopsychosocial factors, student overload, dissatisfaction with school, stress, irritability, insomnia and depression ${ }^{12,13}$.

Headaches may be accompanied by symptoms such as photophobia and/or phonophobia, nausea and/or vomiting, which may lead to self-observed disabilities in daily activities ${ }^{4,28}$. A prevalence of photophobia symptoms associated with impaired mobility was found. Also, photophobia and phonophobia showed a correlation in the impairment of daily activities.

Self-assessed pain intensity in the last three months, through VAS and McGill, presented a moderate pain index. Most reported pain at the time of assessment, being relatively low compared to the previous three months. A study of 90 women divided into two groups (TTH and control) collected a sample of participants' saliva that was used as an indirect marker in pain activity ${ }^{29}$. An increase in the salivary amylase level of the experimental group was observed, matching the results obtained with the McGill application. This fact proves that McGill is an effective subjective questionnaire to measure pain.

Headaches are among the ten most disabling diseases in the world ${ }^{30}$. The disability degree demonstrated in this research was assessed using the MIDAS questionnaire, which identified no or minimal pain disability in most participants over the past three months. However, an important number of individuals with severe disability were found; among them, most had migraines. The association of migraine with a higher degree of disability resembles a study that evaluated 198 college students with headache, where a more significant disability was observed in migraine patients when compared with patients with $\mathrm{TTH}^{31}$.

This disability assessed by MIDAS refers to partial or complete changes in work, household and leisure activities ${ }^{32}$. Most individuals had significant changes related to presenteeism by reducing by half, or less than half, their activities due to headaches. In addition, the greater the disability and impact on individuals' lives, the greater the impairment of overall functionality. This result can be attributed to a cognitive decline during headache episodes. This decline is mainly due to a reduction in process and reading speed, verbal memory and learning in tasks that require attention ${ }^{33,34}$. Thus, there is a negative impact on the health of individuals and this may eventually impact the professional and health care sector economically ${ }^{11}$.
The economic impact related to presenteeism is 2.6 times greater than the number of absences, especially in individuals with episodic and chronic migraine ${ }^{35}$. In this paper, the headache impact on social functioning was classified as severe for most individuals. Individual factors, such as changes in personality, lifestyle, constant physical and psychological stress, economic and marital situations, as well as educational level, may contribute to this result ${ }^{11}$.

Although most individuals had sleep-related disorders, no association was found with the evaluated overall functionality. Contrary to the results found in this research, some authors state that insufficient sleep may be the cause of headache, which also negatively impacts individuals' daily activities ${ }^{36,37}$. A review analyzed the influence of poor sleep and its implications for public health and found that insufficient sleep contributes to the emergence of cardiorespiratory disorders, psychological disorders, diabetes mellitus, migraine, among others $^{38}$. This scarcity of sleep results in changes in behavior in the academic and work environment, with the onset of intellectual, physical and emotional problems.

Whodas is an instrument developed by WHO to measure disability and inability, supporting the International Health Classification model, in a biopsychosocial context, in the cognition, mobility, self-care, interpersonal relationships, and life activities domains $s^{39}$. Although headache is a common comorbidity in the population, its repercussions on activities and social participation, so far, have not been described in the literature. There are no studies with the application of the Whodas instrument in headache patients, which makes this an unprecedented research.

Although patients reported moderate impairment of pain quality and sleep-related aspects, these variables did not correlate with overall functionality aspects assessed by Whodas 2.0. It is suggested that Whodas 2.0's domains, evaluated by the short 12item questionnaire, could have prevented the discrimination of functionality aspects that would be related to these factors. On the other hand, the quality of pain and sleep are subjective and individual aspects, marked by psychological conditions that may vary with the individual's history. Thus, in a sample, the results can be quite variable, preventing a statistical correlation.

\section{CONCLUSION}

According to the results of this study, headache is a condition that intensifies as social attributions expand. Thus, far beyond the disease perspective, this work, in an unprecedented way, demonstrated that the evaluation of personal, social, and family factors is fundamental to understand the headache triggering, the influences on its duration and the potential factors that contribute to its complications.

\section{REFERENCES}

1. Farias N, Buchalla CM. A Classificação Internacional de Funcionalidade, Incapacidade e Saúde da Organização Mundial da Saúde: Conceitos, Usos e Perspectivas. Rev Bras Epidemiol. 2005;8(2):187-93.

2. Bourke J. The headache in history and culture. Art Med. 2017;389(11):77-8. 
3. Rizzoli P, Mullally WJ. Headache. Am J Med. 2018;131(1):17-24.

4. Headache Classification Committee of the International Headache Society (IHS). The International Classification of Headache Disorders, $3^{\text {rd }}$ ed. Cefaleia. 2018;38(1):1-211.

5. Mingels S, Dankaerts W, Granitzer M. Preclinical signs of a temporomandibular disorder in female patients with episodic cervicogenic headache versus asymptomatic controls: a cross-sectional study. PM R. 2019;12.

6. Vetvik KG, MacGregor EA. Sex differences in the epidemiology, clinical features, and pathophysiology of migraine. Lancet Neurol. 2017;(16):76-87.

7. Saylor D, Steiner TJ. The Global Burden of Headache. Semin Neurol. 2018;38(2):182-90.

8. Statculescu AM, Chen Y. Synergism between female gender and high levels of daily stress associated with migraine headaches in Ontario, Canada. Neuroepidemiology. 2018;51(3-4):183-9.

9. Schramm SH, Moebus S, Lehmann N, Galli U, Obermann M, Bock E, et al. The association between stress and headache: a longitudinal population-based study. Cephalalgia. 2015;35(10):853-63.

10. Zampieri MA, Tognola WA, Galego JC. Patients with chronic headache tend to have more psychological symptoms than those with sporadic episodes of pain. Arq Neuropsiquiatr. 2014;72(8):598-602.

11. Muńoz I, Hernández MS, Santos S, Jurado C, Ruiz L, Toribio E, et al. Personality traits in patients with cluster headache: a comparison with migraine patients. J Headache Pain. 2016;17:25.

12. Lebedeva ER, Kobzeva NR, Gilev D, Olesen J. Prevalence of primary headache disorders diagnosed according to ICHD-3 beta in three different social groups. Cephalalgia. 2016;36(6):579-88.

13. Johansson AM, Vikingsson H, Varkey E. The physiotherapist, an untapped resource for headaches: a survey of university students. Eur J Physiother. 2017;20(1):45-50.

14. Ferrer MLP, Perracini MR, Rebustini F, Buchalla CM. WHODAS 2.0-BO: normative data for the assessment of disability in older adults. Rev Saude Publica. 2019;53:19. English, Portuguese.

15. Furtado RN, Ribeiro LH, Abdo Bde A, Descio FJ, Martucci CE Jr, Serruya DC. [Nonspecific low back pain in young adults: associated risk factors]. Rev Bras Reumatol. 2014;54:(5):371-7. Portuguese, English.

16. Vasudha MS, Manjunath NK, Nagendra HR. Changes in MIDAS, perceived stress, frontalis muscle activity and non-steroidal anti-inflammatory drugs usage in patients with migraine headache without aura following ayurveda and yoga compared to controls: an open labeled non-randomized study. Ann Neurosci. 2018;25(4):250-60.

17. Oikonomidi T, Vikelis M, Artemiadis A, Chrousos GP, Darviri C. Reliability and Validity of the Greek Migraine Disability Assessment (MIDAS) Questionnaire. Pharmacoecon Open. 2018;2(1):77-85.

18. Tassorelli C, Diener HC, Dodick DW, Silberstein SD, Lipton RB, Ashina M, et al. Guidelines of the International Headache Society for controlled trials of preventive treatment of chronic migraine in adults. Cephalalgia. 2018;38(5):815-32.

19. Moraska AF, Stenerson L, Butryn N, Krutsch JP, Schmiege SJ, Mann JD. Myofascial trigger point-focused head and neck massage for recurrent tension-type headache: a randomized, placebo-controlled clinical trial. Clin J Pain. 2015;31(2):159-68.

20. Melzack R. The McGill Pain Questionnaire: major properties and scoring methods. Pain. 1975;1(3):277-99.

21. Silva AM, Santos LM, Cerqueira EN, Carvalho ES, Xavier AS. Characterization of pain resulting from perineal trauma in women with vaginal delivery. BrJP. 2018;1(2):158-62.
22. Passos MH, Silva HA, Pitangui AC, Oliveira VM, Lima AS, Araújo RC. Reliability and validity of the Brazilian version of the Pittsburgh Sleep Quality Index in adolescents. J Pediatr. 2017;93(2):200-6.

23. Pedraza MI, Mulero P, Ruíz M, de la Cruz C, Herrero S, Guerrero AL. Characteristics of the first 2,000 patients registered in a specialist headache clinic. Neurologia. 2015;30(4):208-13.

24. Agosti R. Migraine burden of disease: from the patient's experience to a socio-economic view. Headache. 2018;58(1):17-32.

25. Sacco S, Merki-Feld GS, Ægidius KL, Bitzer J, Canonico M, Gantenbein AR, et al. Effect of exogenous estrogens and progestogens on the course of migraine during reproductive age: a consensus statement by the European Headache Federation (EHF) and the European Society of Contraception and Reproductive Health (ESCRH). J Headache Pain. 2018;19(1):76.

26. Andrade AS, Tiraboschi GA, Antunes NA, Viana PV, Zanoto PA, Curilla RT. Vivências acadêmicas e sofrimento psíquico de estudantes de Psicologia. Psicologia: Ciência e Profissão. 2016;36(4):831-46.

27. Pinto JM, Ferreira MM, Costa MB, Garcia SA, Andrade WM, Fernandes CK, et al Frequência de cefaleia em funcionários dos hospitais de uma cidade da Região Oeste II do estado de Goiás. Rev Fac Montes Belos. 2015;8(1):1-15.

28. Cortez MM, Digre K, Uddin D, Hung M, Blitzer A, Bounsanga J, et al. Validation of a photophobia symptom impact scale. Cephalalgia. 2019;0(0):1-10.

29. Vahedi M, Mazdeh M, Hajilooi M, Farhadian M, Barakian Y, Sadr P. Research paper: the relationship between salivary alpha amylase activity and score of McGill pain questionnaire in patients with tension type headache. Basic Clin Neurosci. 2018;9(1):59-64.

30. Global Burden of Disease study 2017 Collaborators. Global, regional, and nationa incidence, prevalence, and years lived with disability for 354 diseases and injuries for 195 countries and territories, 1990-2017: a systematic analysis for the Global Burden of Disease Study 2017. Lancet. 2018;392:1789-858.

31. Queiroz LP, Silva Junior AA. Prevalence and impact of headache in Brazil. Headache. 2015;55(1):32-8.

32. Moura LC, Pereira LB, Moura LC, Pimentel LH. Prevalência de incapacidade por enxaqueca em estudantes de medicina. Rev Bras Neurol Psiquiatr. 2016;20(3):217-29.

33. Gouveia RG, Oliveira AG, Martins I. Cognitive dysfunction during migraine attacks: A study on migraine without aura. Cephalalgia. 2015;35(8):662-74.

34. Baena CP, Goulart AC, Santos IS, Suemoto CK, Lotufo PA, Bensenor IJ. Migraine and cognitive function: Baseline findings from the Brazilian Longitudinal Study of Adult Health: ELSA-Brasil. Cephalalgia. 2018;38(9):1525-34.

35. Leonard M, Raggi A. A narrative review on the burden of migraine: when the burden is the impact on people's life. J Headache Pain. 2019;20(1):41.

36. Kristoffersen ES, Stavem K, Lundqvist C, Russell MB. Excessive daytime sleepiness in secondary chronic headache from the general population. J Headache Pain. 2017;18(1):85.

37. Peñas CFL, Muñoz JJF, Ceña MP, Bravo PP, Méndez MC, Pardo EN. Sleep disturbances in tension-type headache and migraine. Ther Adv Neurol Disord. 2017;11:1-6.

38. Chattu VK, Manzar MD, Kumary S, Burman D, Spence DW, Pandi-Perumal SR. The global problem of insufficient sleep and its serious public health implications. Healthcare. 2018;7(1).

39. Silveira LS, Castro SS, Leite CF, Oliveira NM, Salomão AE, Pereira K. Validade e confiabilidade da versão brasileira do World Health Organization Disability Assessment Schedule em pessoas com cegueira. Fisioter Pesqui. 2019;26(1):22-30. 